\title{
EVIDENCE THAT INHIBITION OF PHORBOL ESTER- INDUCED SUPEROXIDE ANION FORMATION BY CYCLOSPORIN A IN PHAGOCYTES IS NOT MEDIATED BY DIRECT INHIBITION OF PROTEIN KINASE C
}

\author{
Katharina Wenzel-Seifert, ${ }^{*}$ Christoph Schächtele,$\dagger \dagger$ Richard Hummel,$\dagger$ \\ LORE GRÜNBAUM* and ROLAND SEIFERT* $\$$ \\ *Institut für Pharmakologie, Freie Universität Berlin, Thielallee 69/73, D-14195 Berlin; †Institut für \\ Molekulare Zellbiologie; Mosswaldallee 1-9; D-79108 Freiburg, F.R.G.
}

(Received 7 February 1994; accepted 3 June 1994)

\begin{abstract}
Cyclosporin A (CsA) has been reported to inhibit phorbol myristate acetate (PMA)-induced superoxide anion $\left(\mathrm{O}_{2}^{-}\right)$formation in human neutrophils and murine macrophages. We found that CsA inhibited $\mathrm{O}_{2}^{-}$formation in HL-60 cells induced by PMA $(30 \mathrm{nM})$ and phorbol dibutyrate $(200 \mathrm{nM})$ with a half-maximal effect at 1 and $0.75 \mu \mathrm{M}$, respectively. One possible target of CsA action is protein kinase $\mathrm{C}$ (PKC) [EC 2.7.1.37] since phorbol esters activate this kinase. However, CsA did not inhibit PMAmediated reduction of histamine-induced rises in cytosolic $\mathrm{Ca}^{2+}$ concentration in, and PMA-induced differentiation of, HL-60 cells and platelet aggregation. CsA did not reduce the activity of various recombinant $c$-PKC isoenzymes $(\alpha, \beta 1$ and $\gamma), n$-PKC isoenzymes $(\delta$ and $\varepsilon$ ), an $a$-PKC isoenzyme $(\xi)$ nor of PKC purified from rat brain in vitro. These data show that CsA inhibits phorbol ester-induced $\mathrm{O}_{2}^{-}$formation in HL-60 cells but not other phorbol ester-mediated events and that inhibition by CsA of $\mathrm{O}_{2}^{-}$formation cannot readily be attributed to direct $\mathrm{PKC}$ inhibition. We also show that CsA does not change the activity of nucleoside diphosphate kinase [EC 2.7.4.6] in HL-60 membranes nor the latter's physical properties.
\end{abstract}

Key words: cyclosporin A; superoxide anion; phorbol esters; protein kinase C

Phagocytes possess a multi-component NADPH oxidase [EC 1.6.99.6] which catalyses the formation of $\mathrm{O}_{2}^{-} \|$, NADPH being the electron donor [1-3]. Among the regulatory components of NADPH oxidase are small GTP-binding proteins and NDPK [EC 2.7.4.6] [1-3]. $\mathrm{O}_{2}^{-}$formation can be stimulated by formyl peptides and PMA [1-3]. PKC [EC 2.7.1.37] plays a crucial role in NADPH oxidase activation [1-3]. PKC is a family comprising $c_{-}, n-$ and $a-\mathrm{PKC}$ isoenzymes [4-6]. $c$-PKC isoenzymes $(\alpha$, $\beta 1, \beta 2$ and $\gamma$ ) are $\mathrm{Ca}^{2+}$-dependent and are activated by PMA. $n$-PKC isoenzymes $(\delta, \varepsilon, \eta$ and $\theta)$ are activated by phorbol esters as well but are $\mathrm{Ca}^{2+}$ independent. A third group of PKC isoenzymes, $a$ PKC ( $\zeta$ and $\lambda)$, is not substantially activated by phorbol esters and is also $\mathrm{Ca}^{2+}$-independent. Recent data indicate that $n$-PKC isoenzymes are involved

$\ddagger$ Present address: Institut für Molekulare Medizin und Naturstofforschung, Klinik für Tumorbiologie, Breisacherstr. 117, D-79106 Freiburg, F.R.G.

$\S$ Corresponding author. Tel. (49) 30838 2064; FAX 49 308315954.

$\|$ Abbreviations: $\operatorname{ATP}[\gamma \delta]$, adenosine $5^{\prime}-[\gamma$-thio $]$ triphosphate; $\left[\mathrm{Ca}^{2+}\right]_{\mathrm{i}}$, cytosolic $\mathrm{Ca}^{2+}$ concentration; CsA, cyclosporin A; Gö 6850, 2 - (1H-indol-3-yl) - 3-[1 - (3dimethylaminopropyl) - $1 H$-indol - 3 - yl - maleinimide; Gö 6976, 12 - (2-cyanoethyl) - 6,7,12,13-tetrahydro-13-methyl - 5 - oxo - $5 H$ - indolo $[2,3-a]$ pyrrolo $[3,4-c]$ - carbazole; GTP $[\gamma \delta]$, guanosine 5 -[ $\gamma$-thio $]$ triphosphate; NDPK, nucleoside diphosphate kinase; $\mathrm{O}_{2}^{-}$, superoxide anion; PDB, phorbol dibutyrate; PKC, protein kinase C; PMA, phorbol myristate acetate. in PMA- and formyl peptide-induced activation of $\mathrm{O}_{2}^{-}$formation [7].

The immunosuppressant, CsA [8], inhibits PMAinduced $\mathrm{O}_{2}^{-}$formation in murine peritoneal macrophages and human neutrophils [9-11]. In addition, $\mathrm{CsA}$ inhibits formyl peptide-induced $\mathrm{O}_{2}^{-}$formation in neutrophils and HL-60 cells [10-12]. The precise mechanism by which these effects are accomplished is poorly understood. With regard to $c$-PKC isoenzymes, both inhibitory effects and the lack of effect of CsA on enzyme activity have been reported $[13,14]$. The aim of the present study was to learn more about the mechanism underlying the inhibitory effect of $\mathrm{Cs} \mathrm{A}$ on $\mathrm{O}_{2}^{-}$formation, especially inasmuch as $\mathrm{CsA}$ is a direct inhibitor of $n-\mathrm{PKC}$ isoenzymes.

\section{MATERIALS AND METHODS}

Materials. CsA was kindly provided by Sandoz (Basel, Switzerland). A stock solution of CsA $(1 \mathrm{mM})$ was prepared in $100 \%(\mathrm{v} / \mathrm{v})$ dimethyl sulfoxide and stored in polypropylene tubes at $-20^{\circ}$ under light protection for up to 4 weeks. The final dimethyl sulfoxide concentration in assays was adjusted to $0.3 \%(\mathrm{v} / \mathrm{v})$. PMA and PDB were obtained from Sigma Chemie (Deisenhofen, F.R.G.). [Serine ${ }^{25}$ ]PKC(19-31) was obtained from Peninsula (Belmont, CA, U.S.A.). Gö 6850 and Gö 6976 were provided by Gödecke AG (Freiburg, F.R.G.). $\left[\gamma^{32}\right.$ P]ATP (3 Ci/mmol) was obtained from Amersham (Braunschweig, F.R.G.). Sources of 
other materials have been described elsewhere $[7,10,12,15-21]$.

Cell culture. HL-60 cells were cultured in suspension culture at $37^{\circ}$ and differentiated towards neutrophil-like cells upon incubation with dibutyryl cAMP $(0.2 \mathrm{mM})$ for $48 \mathrm{hr}[15]$. In other experiments, HL-60 cells were differentiated towards macrophagelike cells with PMA (10-100 nM) for $96 \mathrm{hr}$ [22].

Assay for $\mathrm{O}_{2}^{-}$formation in $\mathrm{HL}-60$ cells. $\mathrm{O}_{2}^{-}$ formation was monitored at $550 \mathrm{~nm}$ by continuous measurement of ferricytochrome $C$ reduction inhibitable by superoxide dismutase, using an Uvikon 810 dual beam spectrophotometer (Kontron, Eching, F.R.G.) [15]. Reaction mixtures $(0.5 \mathrm{~mL})$ contained $100 \mu \mathrm{M}$ ferricytochrome $C$ and a buffer consisting of $138 \mathrm{mM} \mathrm{NaCl}, 6 \mathrm{mM} \mathrm{KCl}, 1 \mathrm{mM} \mathrm{MgCl}_{2}, 1 \mathrm{mM}$ $\mathrm{CaCl}_{2}, 5.5 \mathrm{mM}$ glucose and $20 \mathrm{mM}$ Hepes/ $\mathrm{NaOH}$, pH 7.4. HL-60 cells $\left(2.5 \times 10^{6}\right.$ cells/cuvette $)$ were suspended in the solution described above and incubated for $3 \mathrm{~min}$ in the presence of solvent (control) or various concentrations of CSA at $37^{\circ}$. $\mathrm{O}_{2}^{-}$formation was initiated by the addition of stimuli. The maximum rates of $\mathrm{O}_{2}^{-}$formation were calculated.

Measurement of $\left[\mathrm{Ca}^{2+}\right]_{i}$. $\left[\mathrm{Ca}^{2+}\right]_{i}$ was determined using the fluorescent dye, Fura-2, as described previously [16]. Fluorescence of HL-60 cells $\left(1.0 \times 10^{6}\right.$ cells in $\left.2 \mathrm{~mL}\right)$ was determined at $37^{\circ}$ under constant stirring at $10^{3} \mathrm{rpm}$ using a Ratio II spectrofluorometer (Aminco, Silver Spring, MD, U.S.A.). Cells were incubated for $3 \mathrm{~min}$ in the absence or presence of CsA before the addition of solvent (control) or PMA. After an additional $3 \mathrm{~min}$, stimulus was added to the cells.

Platelet aggregation. Isolation of platelets from healthy drug-free volunteers was performed as described previously [17]. Platelet aggregation was studied in an Aggrecorder II PA-3220 (Kyoto Daiichi Kagaku, Kyoto, Japan) according to Berg et al. [17]. Solvent (control) or CsA was added to platelets $3 \mathrm{~min}$ before the addition of stimuli.

Preparation of recombinant PKC isoenzymes and purification of $P K C$ from rat brain. Full-length human cDNAs for PKC isoenzymes $\alpha, \beta 1$, and $\zeta$, rat cDNA for PKC isoenzyme $\gamma$ and mouse cDNAs for PKC isoenzymes $\delta$ and $\varepsilon$ were inserted into the baculovirus expression vector, pVL1393 [18, 23]. Expression of $\mathrm{PKC}$ isoenzymes in $\mathrm{Sf} 9$ insect cells and purification of expressed enzymes were performed as described elsewhere [18]. PKC from rat brain was prepared according to the procedure described by Inagaki et al.[24]. This purification resulted in a mixed preparation of the four c-PKC isoenzymes as revealed by immunoblotting with isoenzyme-specific antibodies (data not shown).

Determination of PKC activity. For determination of PKC activity, reaction mixtures $(200 \mu \mathrm{L})$ contained 5-10 units of PKC (1 unit transfers 1 pmol of phosphate $/ \mathrm{min}), 10 \mu \mathrm{M}\left[\gamma_{-}^{32} \mathrm{P}\right] \mathrm{ATP}(0.2 \mu \mathrm{Ci} /$ tube $)$, $40 \mu \mathrm{g}$ of histone $\mathrm{H}_{1}, 5 \mathrm{mM} \mathrm{MgCl}_{2}, 1 \mathrm{mM}$ EDTA, $1.25 \mathrm{mM}$ EGTA, $1.32 \mathrm{mM} \mathrm{CaCl}_{2}, 1 \mathrm{mM}$ dithiothreitol, $1 \mu \mathrm{g}$ of phosphatidylserine and $0.2 \mu \mathrm{g}$ of diolein in $50 \mathrm{mM}$ Hepes/ $\mathrm{NaOH}, \mathrm{pH} 7.5$. Reaction mixtures additionally contained solvent (control), CsA or Gö 6850. Reactions were initiated by the addition of $\left[\gamma^{32} \mathrm{P}\right] \mathrm{ATP}$ and conducted for $5 \mathrm{~min}$ at $30^{\circ}$. Reactions were terminated by the addition of $2 \mathrm{~mL}$ of $8.5 \%(\mathrm{w} / \mathrm{v}) \mathrm{H}_{3} \mathrm{PO}_{4}$ and filtration through $0.45 \mu \mathrm{m}$ Sartorius nitrocellulose filters. Radioactivity

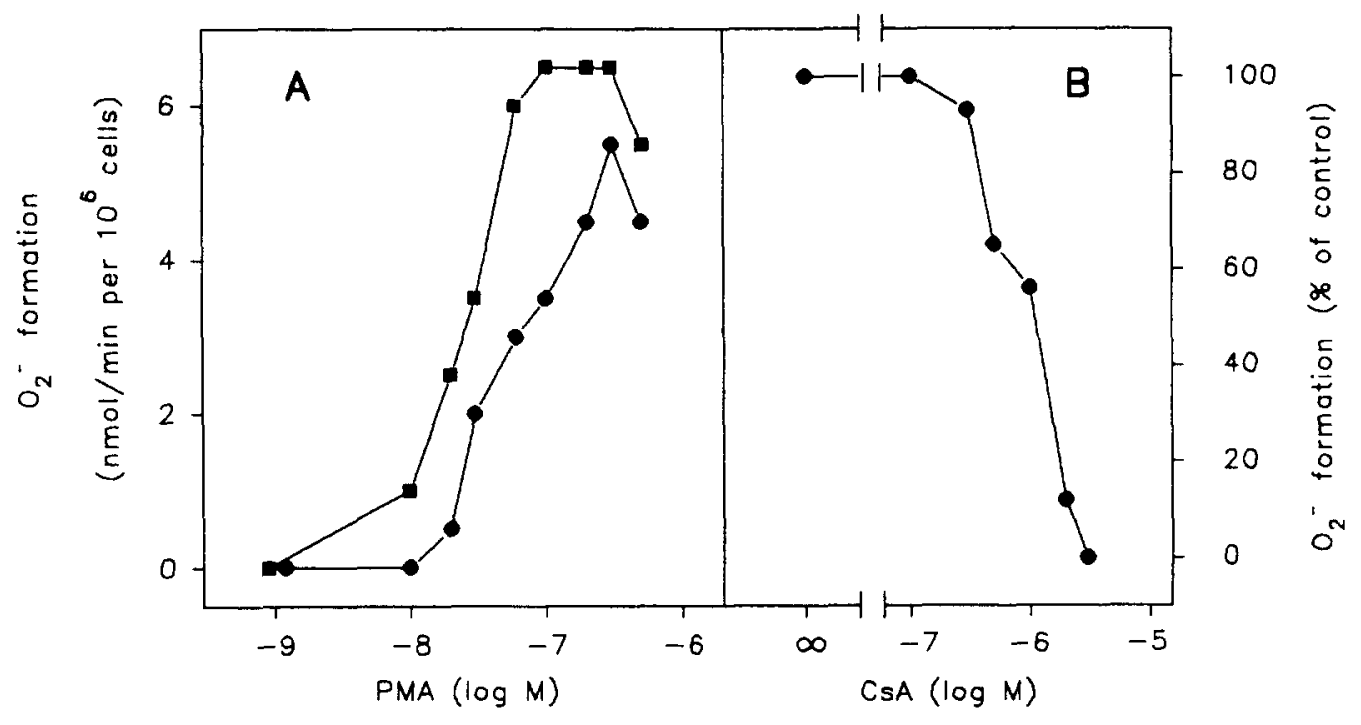

Fig. 1. Effect of CsA on PMA-induced $\mathrm{O}_{2}^{-}$formation in HL-60 cells. $\mathrm{O}_{2}^{-}$formation was determined as described in Materials and Methods. (A) Concentration-response curve to PMA. CsA $(1 \mu \mathrm{M})(0)$ or solvent (control) (ש) was added to reaction mixtures 3 min before the addition of PMA at the indicated concentrations. (B) Concentration-response curve to CsA. CsA was added to reaction mixtures 3 min before the addition of PMA $(30 \mathrm{nM}) . \mathrm{O}_{2}^{-}$formation in the presence of solvent (control) amounted to $3.64 \pm 0.21 \mathrm{nmol} / \mathrm{min}$ per $10^{6}$ cells. Data shown are the means of four experiments carried out with different preparations of HL-60 cells. The SD values of the data were generally $<10 \%$ of the means. 
bound to filters was determined in a liquid scintillation spectrometer. Reaction mixtures for determination of PKC isoenzyme $\zeta$ activity contained $2 \mu \mathrm{g}$ of [serine ${ }^{25}$ ]PKC(19-31) rather than histone $\mathrm{H}_{1}$ as phosphate acceptor, and P81 Whatman phosphocellulose filters were used instead of nitrocellulose filters [25]. As phospholipid-dependent activity of PKC isoenzyme $\zeta$ is very low $[5,18]$, the total incorporation of phosphate into [serine $\left.{ }^{25}\right] \mathrm{PKC}(19$ 31) was regarded as enzyme activity.

Measurement of NDPK activity. GTP $[\gamma]$ formation was determined as described previously [23]. Reaction mixtures $(50 \mu \mathrm{L})$ contained HL-60 membranes (40 $\mu \mathrm{g}$ of protein/tube), $0.5 \mu \mathrm{M}\left[{ }^{3} \mathrm{H}\right]$ GDP $(1 \mu \mathrm{Ci} /$ tube $), 50 \mu \mathrm{M}$ ATP $[\gamma \mathrm{S}], 2 \mathrm{mM} \mathrm{MgCl}$, $0.1 \mathrm{mM}$ EGTA, $1 \mathrm{mM}$ dithiothreitol and $0.2 \%$ $(\mathrm{w} / \mathrm{v}) \mathrm{BSA}$ in $50 \mathrm{mM}$ triethanolamine $/ \mathrm{HCl}, \mathrm{pH} 7.4$. Reaction mixtures additionally contained solvent (control) or CsA. Reactions were conducted for $15 \mathrm{~min}$ at $25^{\circ}$. Nucleotides were separated by TLC and eluted from TLC plates as described [19].

Steady-state and differential polarized phase fluorometry. Determination of steady-state and differential phase fluorescence of 1,6diphenylhexa-1,3,5-triene-loaded HL-60 membranes was performed as described [20]. Membranes were incubated for $10 \mathrm{~min}$ at $25^{\circ}$ in the presence of solvent (control) or CsA. Fluorescence measurements were performed at $25^{\circ}$ in a SLM 4800 spectrofluorometer (SLM Instruments, Urbana, IL, U.S.A.) equipped with a thermostated cuvette holder.

ATPase [EC 3.6.1.3] assays. Determination of the activities of $\mathrm{Na}^{+} / \mathrm{K}^{+}$-ATPase and $\mathrm{Mg}^{2+}$-ATPase in HL- 60 membranes was performed as described by
Ebel et al. [21]. Reaction mixtures $(100 \mu \mathrm{L})$ contained $6.0 \mu \mathrm{g}$ of protein and solvent (control) or CsA. The amount of inorganic phosphate in supernatant fluids of reaction mixtures was determined according to Ames [26].

Miscellaneous. Protein was determined according to Lowry et al. [27]. HL-60 membranes were prepared as described [19].

\section{RESULTS}

We first studied the effects of CsA, Gö 6850 and Gö 6976 on phorbol ester-induced $\mathrm{O}_{2}^{-}$formation in HL-60 cells. PMA activated $\mathrm{O}_{2}^{-}$formation with a half-maximal effect at $25 \mathrm{nM}$ and a maximum effect at $100 \mathrm{nM}$ (Fig. 1). When compared to PMA, PDB was similarly effective but about 10 -fold less potent at activating $\mathrm{O}_{2}^{-}$formation (Fig. 2). CsA $(1 \mu \mathrm{M})$ inhibited $\mathrm{O}_{2}^{-}$formation induced by PMA and PDB at submaximally and maximally effective concentrations of the stimuli. The inhibitory effect of CsA on $\mathrm{O}_{2}^{-}$formation induced by PMA ( $\left.30 \mathrm{nM}\right)$ was half-maximal at $1 \mu \mathrm{M}$ and was complete at $3 \mu \mathrm{M}$ (see Fig. 1). With respect to $\mathrm{O}_{2}^{-}$formation induced by PDB $(200 \mathrm{nM})$, the inhibitory effect of CsA was half-maximal at $0.75 \mu \mathrm{M}$ and maximal at $3 \mu \mathrm{M}$ (see Fig. 2). Gö $6850(1 \mu \mathrm{M})$, an inhibitor of $c$ - and $n$ PKC isoenzymes [18], abolished the stimulatory effects of PMA on $\mathrm{O}_{2}^{-}$formation, whereas Gö 6976 $(1 \mu \mathrm{M})$, a selective inhibitor of c-PKC isoenzymes [18], was ineffective (data not shown). These data are in agreement with those obtained with human neutrophils and substantiate the view that $n$-PKC

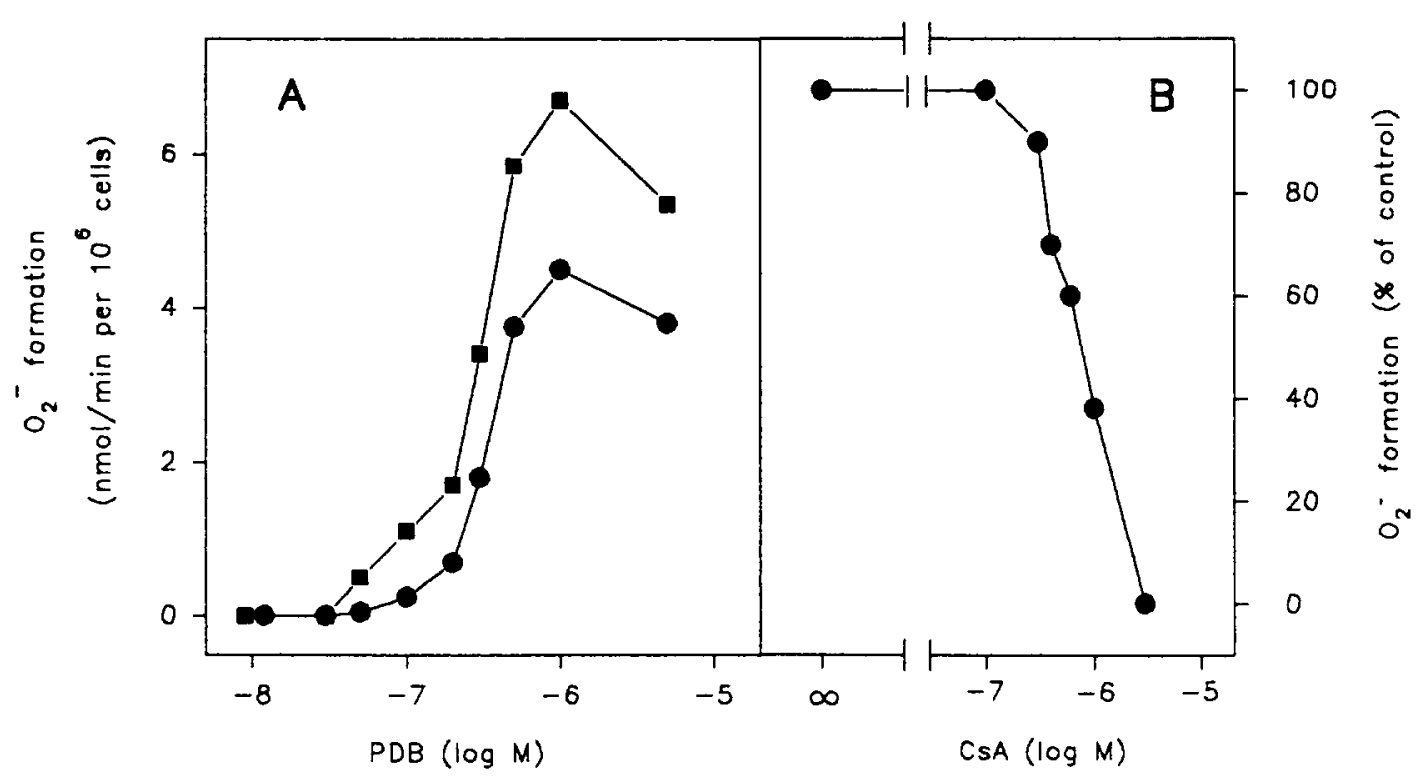

Fig. 2. Effect of CsA on PDB-induced $\mathrm{O}_{2}^{-}$formation in HL-60 cells. $\mathrm{O}_{2}^{-}$formation was determined as described in Materials and Methods. (A) Concentration-response curve to PDB. CsA $(1 \mu \mathrm{M})(\mathbf{O})$ or solvent (control) (ם) was added to reaction mixtures $3 \mathrm{~min}$ before the addition of PDB at the indicated concentrations. (B): Concentration-response curve to CsA. CsA was added to reaction mixtures $3 \mathrm{~min}$ before the addition of PDB $(200 \mathrm{nM}) . \mathrm{O}_{2}^{-}$formation in the presence of solvent (control) amounted to $1.85 \pm 0.10 \mathrm{nmol} / \mathrm{min}$ per $10^{6}$ cells. Data shown are the means of four experiments carried out with different preparations of HL-60 cells. The SD values of the data were generally $<10 \%$ of the means. 
Table 1. Effects of CsA and Gö 6850 on the activity of recombinant PKC isoenzymes $\alpha, \beta 1, \gamma, \delta, \varepsilon$ and $\zeta$ and PKC purified from rat brain

\begin{tabular}{|c|c|c|}
\hline \multirow[b]{2}{*}{ Enzyme } & \multicolumn{2}{|c|}{$\begin{array}{c}\text { Enzyme activity } \\
\text { (\% of control) }\end{array}$} \\
\hline & $\operatorname{CsA}$ & Gö 6850 \\
\hline PKC isoenzyme $\alpha$ & 98 & 6 \\
\hline $\mathrm{PKC}$ isoenzyme $\beta 1$ & 100 & 18 \\
\hline PKC isoenzyme $\gamma$ & 113 & 12 \\
\hline PKC isoenzyme $\delta$ & 104 & 2 \\
\hline PKC isoenzyme $\varepsilon$ & 108 & 0 \\
\hline $\mathrm{PKC}$ isoenzyme $\zeta$ & 104 & ND \\
\hline PKC from rat brain $(\alpha, \beta 1, \beta 2, \gamma)$ & 100 & 3 \\
\hline
\end{tabular}

The activity of PKC was determined as described in Materials and Methods. Enzyme activity refers to that observed in the presence of solvent (control). CsA was employed at a concentration of $10 \mu \mathrm{M}$ throughout. In experiments with PKC isoenzymes $\alpha, \beta 1$ and $\gamma$ and PKC purified from rat brain, Gö 6850 was employed at a concentration of $300 \mathrm{nM}$, and in experiments with PKC isoenzymes $\varepsilon$ and $\delta$, Gö 6850 concentration was $10 \mu \mathrm{M}$. Data shown are the means of two independent experiments performed in triplicate. The SD values of the data were generally $<5 \%$ of the means.

$\mathrm{ND}$, not done.

isoenzymes are involved in PMA-mediated activation of NADPH oxidase [7].

In addition to activation of $\mathrm{O}_{2}^{-}$formation, PMA shows numerous other biological effects: e.g., inhibition of receptor agonist-induced rises in $\left[\mathrm{Ca}^{2+}\right]_{\mathrm{i}}[16]$, induction of macrophage-like differentiation of HL-60 cells [22] and activation of platelet aggregation [28]. PMA ( $2 \mathrm{nM})$ abolished the stimulatory effect of histamine $(100 \mu \mathrm{M})$ on $\left[\mathrm{Ca}^{2+}\right]_{\mathrm{i}}$ in HL-60 cells, but CsA $(1 \mu \mathrm{M})$ could not revert this inhibition (data not shown). In addition, PMA (10$100 \mathrm{nM}$ ) induced macrophage-like differentiation of HL-60 cells as assessed by adherence and changes in morphology. Again, CsA $(1 \mu \mathrm{M})$ did not prevent the phorbol ester effect (data not shown). Moreover, PMA induced aggregation of human platelets with a half-maximal effect at $10 \mathrm{nM}$ and a maximum at $100 \mathrm{nM}$, but CsA $(1 \mu \mathrm{M})$ did not affect platelet aggregation induced by PMA (data not shown).

The effects of CsA on the activity of recombinant PKC isoenzymes $\alpha, \beta 1, \gamma, \delta, \varepsilon$ and $\zeta$ and on $c$-PKC isoenzymes purified from rat brain were studied in vitro (Table 1). CsA ( 1 and $10 \mu \mathrm{M}$, data for CsA at $1 \mu \mathrm{M}$ not shown) did not substantially reduce the activity of any of the PKC isoenzymes studied. In addition, CsA $(1$ and $10 \mu \mathrm{M})$ did not affect the activity of PKC purified from rat brain. By contrast to $\mathrm{CsA}$, Gö 6850 strongly reduced the activity of $c$ and $n$-PKC isoenzymes and of PKC purified from rat brain (see Table 1).

The effect of CsA on NDPK-catalysed GTP[ $\gamma S]$ formation in HL-60 membranes was studied. NDPK catalysed the formation of $9.4 \pm 0.8$ pmoles of GTP $[\gamma \mathrm{S}]$ from GDP and ATP $[\gamma \mathrm{S}] / \mathrm{mg}$ (mean $\pm \mathrm{SD}$, $\mathrm{N}=6)$. CsA (1 and $10 \mu \mathrm{M})$ had no effect on this GTP $[\gamma \delta]$ formation (data not shown).

We also studied the effect of CsA on physical properties of HL-60 membranes using steadystate polarization and differential polarized phase fluorometry with 1,6-diphenylhexa-1,3,5-triene probe $[20]$. We assessed limiting anisotropy and rotational correlation time. Limiting anisotropy in HL-60 membranes treated with solvent (control) was $0.175 \pm 0.002$, and rotational correlation time was $1.445 \pm 0.106 \mathrm{nsec}$ (means $\pm \mathrm{SD}, \mathrm{N}=3$ ). CsA ( $1 \mu \mathrm{M})$ did not change these values (data not shown).

Finally, we studied the effects of CsA on the activity of $\mathrm{Mg}^{2+}$-ATPase and $\mathrm{Na}^{+} / \mathrm{K}^{+}$-ATPase in HL-60 membranes. The activity of these enzymes was $0.25 \pm 0.03 \mu \mathrm{mol} / \mathrm{mg} / \mathrm{min}$ and $0.14 \pm 0.01 \mu \mathrm{mol} /$ $\mathrm{mg} / \mathrm{min}$, respectively (means $\pm \mathrm{SD}, \mathrm{N}=4)$. CsA ( 1 , 3 and $10 \mu \mathrm{M}$ ) had no effect on $\mathrm{Mg}^{2+}$-ATPase and $\mathrm{Na}^{+} / \mathrm{K}^{+}-$ATPase (data not shown).

\section{DISCUSSION}

In agreement with the data obtained with human neutrophils and murine peritoneal macrophages [9-11], we found that CsA inhibits phorbol esterinduced $\mathrm{O}_{2}^{-}$formation in HL-60 cells (see Figs 1 and 2 ). We tested various hypotheses in an attempt to explain these effects of CsA.

PMA- and formyl peptide-mediated $\mathrm{O}_{2}^{-}$formation involves activation of $n$-PKC isoenzymes [7], and CsA inhibits $\mathrm{O}_{2}^{-}$formation induced by both stimuli (see Figs 1 and 2) [9-12]. From these findings, the question arises as to whether CsA inhibits these $\mathrm{PKC}$ isoenzymes. Due to the fact that purification to homogeneity of $n$-PKC isoenzymes from tissues or cells is difficult to perform, we used recombinant $n$-PKC isoenzymes. Unlike Gö 6850, CsA had no effect on two $n$-PKC isoenzymes (see Table 1). Additionally, CsA did not inhibit a recombinant $a$ PKC isoenzyme (see Table 1). Furthermore, and in close agreement with the data obtained by Szamel et al. [14] who studied human lymphocytes, we could not detect an inhibitory effect of CsA on $c$-PKC isoenzymes, regardless of whether recombinant enzymes or enzymes purified from rat brain were used (see Table 1). Moreover, CsA failed to revert PMA-mediated inhibition of agonist-induced rises in $\left[\mathrm{Ca}^{2+}\right]_{i}$ in HL-60 cells, PMA-mediated differentiation of these cells, PMA-mediated platelet aggregation or various effects of PMA in human lymphocytes [14]. All these data render it unlikely that PMA inhibits $\mathrm{O}_{2}^{-}$formation through direct inhibition of a known PKC isoenzyme.

Thus, does CsA interfere with a component specifically involved in NADPH oxidase activation? A candidate in this regard is NDPK which catalyses thiophosphorylation of GDP to GTP $[\gamma \delta]$, ATP $[\gamma \delta]$ being the thiophosphoryl group donor [19]. The newly formed GTP $[\gamma]$ then potentiates $\mathrm{O}_{2}^{-}$ formation through activation of GTP-binding proteins [19]. However, CsA does not interfere with NDPK. Previous studies have already shown that CsA is not a formyl peptide receptor antagonist and does not interfere with GTP-binding proteins or the mechanisms leading to rises in $\left[\mathrm{Ca}^{2+}\right]_{i}[9,10,12]$. Moreover, CsA does not inhibit the catalytic domain of NADPH oxidase and does not scavenge $\mathrm{O}_{2}^{-}$or inhibit glucose transport or energy metabolism $[9,10]$. 
CsA interacts with phospholipid bilayers and has been shown to alter the physical properties of lymphocyte membranes $[29,30]$. In addition, it has been reported to inhibit $\mathrm{NA}^{+} / \mathrm{K}^{+}$-ATPase, a membrane-bound enzyme which is sensitive to changes in physical membrane state [31], in lymphocytes [32]. These findings raise the question of whether CsA inhibits $\mathrm{O}_{2}^{-}$formation through alterations in physical membrane properties. However, CsA did not affect limiting anisotropy (a static measure) [20] and rotational correlation time (a dynamic measure) [20] of a fluorescent probe in HL-60 membranes, nor did it affect the activity of $\mathrm{NA}^{+} / \mathrm{K}^{+}$-ATPase and $\mathrm{Mg}^{2+}$-ATPase in HL-60 membranes. These findings render it unlikely that CsA inhibits $\mathrm{O}_{2}^{-}$formation through changes in physical membrane properties.

In conclusion, we have shown that CsA inhibits phorbol ester-induced $\mathrm{O}_{2}^{-}$formation in HL-60 cells but not other phorbol ester-mediated events. Inhibition by $\mathrm{CsA}$ of $\mathrm{O}_{2}^{-}$formation cannot readily be attributed to direct PKC inhibition, interference with known components of NADPH oxidase or changes in physical membrane properties. Thus, our results clearly emphasize the need for additional work to elucidate the mechanism by which CsA inhibits $\mathrm{O}_{2}^{-}$formation.

Acknowledgements-The authors are grateful to Dr $\mathrm{H}$. Mischak (Laboratory of Genetics, Molecular Genetics Section, National Cancer Institute, Bethesda, MD, U.S.A.) for supply of the cDNAs of PKC isoenzymes $\delta$ and $\varepsilon$; to Prof. Dr G. Schultz and Dr I. Musgrave for helpful suggestions; to Prof. Dr H. Ebel (Institut für Klinische Physiologie, Universitätsklinikum Steglitz, Freie Universität Berlin) for supply of the SLM-spectrofluorometer and helpful advice; and to Mrs M. Christowa, Mrs E. Glaß and Mrs B. Papanis for expert technical assistance. This work was supported by grants from the Deutsche Forschungsgemeinschaft.

\section{REFERENCES}

1. Rossi $\mathrm{F}$, The $\mathrm{O}_{2}^{-}$-forming NADPH oxidase of phagocytes: nature, mechanisms of activation and function. Biochim Biophys Acta 853: 65-89, 1986.

2. Seifert R and Schultz G, The superoxide-forming NADPH oxidase of phagocytes: an enzyme system regulated by multiple mechanisms. Rev Physiol Biochem Pharmacol 117: 1-338, 1991.

3. Bokoch GM, Biology of the rap proteins, members of the ras superfamily of GTP-binding proteins. Biochem J 289: 17-24, 1993.

4. Asaoka Y, Nakamura S, Yoshida K and Nishizuka $\mathrm{Y}$, Protein kinase $\mathrm{C}$, calcium and phospholipid degradation. Trends Biochem Sci 17: 414-417, 1992.

5. Azzi A, Boscoboinik D and Hensey C, The protein kinase C family. Eur J Biochem 208: 547-557, 1992.

6. Hug $\mathrm{H}$ and Sarre TF, Protein kinase $\mathrm{C}$ isoenzymes: divergence in signal transduction? Biochem J 291: 329 343, 1993.

7. Wenzel-Seifert K, Schächtele $C$ and Seifert R, Nprotein kinase $C$ isoenzymes may be involved in the regulation of various neutrophil functions. Biochem Biophys Res Commun 200: 1536-1543, 1994.

8. Faulds DF, Goa KL and Benfield P, Cyclosporin. A review of its pharmacodynamic and pharmacokinetic properties, and therapeutic use in immunoregulatory disorders. Drugs 45: 953-1040, 1993.

9. Chiara MD, Bedoya F and Sobrino F, Cyclosporin A inhibits phorbol ester-induced activation of superoxide production in resident mouse peritoneal macrophages. Biochem J 264: 21-26, 1989.

10. Wenzel-Seifert K, Grünbaum $L$ and Seifert $R$, Differential inhibition of human neutrophil activation by cyclosporins $\mathrm{A}, \mathrm{D}$ and $\mathrm{H}$. Cyclosporin $\mathrm{H}$ is a potent and effective inhibitor of formyl peptide-induced superoxide formation. J Immunol 147: 1940-1946, 1991.

11. Kurokawa T, Nonami T, Kobayashi H, Kishimoto W, Uchida K, Takagi $H$, Sugiyama $S$ and Ozawa $T$, Inhibition by cyclosporin of the production of superoxide radicals. New Engl J Med 326: 840, 1992.

12. Wenzel-Seifert $K$ and Seifert $R$, Cyclosporin $H$ is a potent and selective formyl peptide receptor antagonist. Comparison with $N$ - $t$-butoxycarbonyl-L-phenylalanyl - L - leucyl - L - phenylalanyl - L - leucyl - L-phenylalanine and cyclosporins A, B, C, D and E. J Immunol 150: 4591-4599, 1993

13. Walker RJ, Lazzaro VA, Duggin GG, Horvath JS and Tiller DJ, Cyclosporin A inhibits protein kinase C activity: a contributing mechanism in the development of nephrotoxicity? Biochem Biophys Res Commun 160: 409-415, 1989.

14. Szamel M, Bartels F and Resch K, Cyclosporin A inhibits $T$ cell receptor-induced interleukin-2 synthesis of human $\mathrm{T}$ lymphocytes by selectively preventing a transmembrane signal transduction pathway leading to sustained activation of a protein kinase $C$ isoenzyme, protein kinase C- $\beta$. Eur $J$ Immunol 23: 3072-3081, 1993.

15. Seifert R, Burde R and Schultz G, Activation of NADPH oxidase by purine and pyrimidine nucleotides involves $G$ proteins and is potentiated by chemotactic peptides. Biochem $J$ 259: 813-819, 1989

16. Seifert R, Höer A, Offermanns S, Buschauer A and Schunack W, Histamine increases cytosolic $\mathrm{Ca}^{2+}$ in dibutyryl-cAMP-differentiated $\mathrm{HL}-60$ cells via $\mathbf{H}_{1}$ receptors and is an incomplete secretagogue. Mol Pharmacol 42: 227-234, 1992.

17. Berg M, Offermanns S, Seifert R and Schultz G,

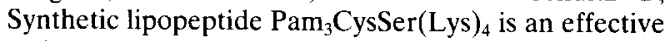
activator of human platelets. Am J Physiol, in press.

18. Martiny-Baron G, Kazanietz MG, Mischak $\mathrm{H}$, Blumberg PM, Kochs G, Hug H, Marmé D and Schächtele $C$, Selective inhibition of protein kinase $C$ isozymes by the indolcarbazole Gö 6976. J Biol Chem 268: 9194-9197, 1993.

19. Seifert R, Rosenthal W, Schultz G, Wieland T, Gierschik $\mathrm{P}$ and Jakobs KH, The role of nucleosidediphosphate kinase reactions in $\mathrm{G}$ protein activation of NADPH oxidase by guanine and adenine nucleotides. Eur J Biochem 175: 51-55, 1988.

20. Wenzel-Seifert $\mathbf{K}$ and Seifert $\mathbf{R}$, Partial inhibition of human neutrophil activation by FK-506 at supratherapeutic concentrations. Naunyn-Schmiedeberg's Arch Pharmacol 348: 7-13, 1993.

21. Ebel H, Aulbert E and Merker HJ, Isolation of the basal and lateral plasma membranes of rat kidney tubule cells. Biochim Biophys Acta 433: 531-546, 1976.

22. Morin MJ, Kreutter D, Rasmussen D and Satorelli AC, Disparate effects of activators of protein kinase Con HL-60 promyelocytic leukemia cell differentiation. J Biol Chem 262: 11758-11763, 1987.

23. Knopf JL, Lee M-H, Sultzman A, Kriz RW, Loomis $\mathrm{CR}$, Hewick RM and Bell RM, Cloning and expression of multiple protein kinase C cDNAs. Cell 46: 491-502, 1986.

24. Inagaki $\mathrm{M}$, Watanabe $\mathrm{M}$ and Hidaka $\mathrm{H}, \mathrm{N}$ (2-Aminoethyl)-5-isoquinolinesulfonamide, a newly synthesized protein kinase inhibitor, functions as a 
ligand in affinity chromatography. Purification of $\mathrm{Ca}^{2+}$. activated, phospholipid-dependent and other protein kinases. J Biol Chem 260: 2922-2925, 1985.

25. Kochs G, Hummel R, Meyer D, Hug H, Marmé D and Sarre TF, Activation and substrate specificity of the human protein kinase $\mathrm{C} \alpha$ and $\zeta$ isoenzymes. Eur $J$ Biochem 216: 597-606, 1993.

26. Ames BN, Assay of inorganic phosphate, total phosphate and phosphatases. Methods Enzymol 8: 115-118, 1966.

27. Lowry OH, Rosebrough NJ, Farr AL and Randall RJ, Protein measurement with the Folin phenol reagent. $J$ Biol Chem 193: 265-275, 1951

28. Siess W, Molecular mechanisms of platelet activation. Physiol Rev 69: 58-178, 1989.

29. Wiedmann TS, Trouard T, Shekar SC, Polikandritou
$\mathrm{M}$ and Rahman Y-E, Interaction of cyclosporin A with dipalmitoylphosphatidylcholine. Biochim Biophys Acta 1023: $12-18,1990$.

30. Niebylski $C D$ and Petty HR, Cyclosporine A induces an early and transient rigidification of lymphocyte membranes. J Leukocyte Biol 49: 407-415, 1991.

31. Giraud F, Claret M, Bruckdorfer KR and Chailley B, The effects of membrane lipid order and cholesterol on the internal and external cationic sites of the $\mathrm{Na}^{+}$. $\mathrm{K}^{+}$-pump in erythrocytes. Biochim Biophys Acta 647: 249-258, 1981

32. Anderson R, Smit $\mathrm{MJ}$ and van Rensburg EJ, Lysophospholipid-mediated inhibition of $\mathrm{Na}^{+}, \mathrm{K}^{+}$adenosine triphosphatase is a possible mechanism of immunosuppressive activity of cyclosporin A. Mol Pharmacol 44: 605-614, 1993. 